\title{
What Almost Was: The Politics of the Contemporary Alternate History Novel
}

\author{
Matthew Schneider-Mayerson
}

Between August of 1995 and July of 1996, Speaker of the House of Representatives Newt Gingrich published two books. One, To Renew America, a folksy Republican polemic cobbled together from Gingrich's speeches, served as a sequel to Contract with America, the blueprint of the conservative movement that assumed control of Congress in $1995 .^{1}$ The other was 1945 , coauthored with William R. Forstchen, a novel set in an alternate universe. ${ }^{2}$ In 1945 's divergent timeline, Germany does not declare war on the United States, the Soviet Union is split into fragments, and the United States and Germany have settled into a cold war. Nazi soldiers parachute into the United States to a capture a nuclear facility in Tennessee, but posses of arms-bearing American veterans successfully defend their country. 1945 was representative of the flourishing genre of alternate history novels in all but two ways: an author's celebrity and its media exposure. Due to Gingrich's status as the public leader of the conservative renaissance of the mid-1990s, 1945 was widely reviewed in mainstream publications. Treated as a curiosity and ridiculed for its poor literary quality, very few reviewers noted the libertarian themes in 1945, and even fewer placed it in the context of an inchoate literary genre. ${ }^{3}$

1995 can be considered the birth year of the alternate history novel as a genre. As a conceptual category, the counterfactual, as historians term their what-if narratives, has been pursued in print since classical Greece, if not earlier. (In a broad sense, anyone who has wondered "what if?" could be said to be an alternate 
historian.) In the twentieth century, alternate histories and counterfactuals, also known as "allohistories," have been published by fiction writers and maverick historians around the world. As Gavriel Rosenfeld discusses in his encyclopedic chronicle of Nazi-related alternate history culture, the production of allohistorical cartoons, films, and stories increased sharply in the wake of the Holocaust, which continues to provide subject matter for alternate historians. ${ }^{4}$ While hundreds of texts can be retroactively added to the list of alternate histories, the version of the literary counterfactual that rose to prominence in the early 1990s was not fully recognized as a genre until science-fiction reviewers Steven H. Silver and Evelyn Leeper and NASA scientist Robert B. Schmunk established the Sidewise Awards for Alternate History in 1995. ${ }^{5}$ The Sidewise Award defined the alternate history as a literary category and became a mechanism to draw and police the borders of the genre. Each year a panel of judges, ranging from three to eight in number, awards a Sidewise to one novel and one short story and lists the runners up. ${ }^{6}$ The authority and aesthetic judgments of the Sidewise Award panel seem to be unchallenged among publishers (on book jackets), authors, and fans around the Internet. ${ }^{7}$ Unlike awards for mainstream literary genres, such as the Pulitzer Prizes and National Book Awards, the Sidewise Awards seems to recognize both a combination of literary excellence and popularity, as demonstrated by the proportional representation of popular and prolific alternate history writers such as Harry Turtledove in the winner's circle.

In this paper, I consider the contemporary alternate history genre in three parts. First, I account for the birth of the genre, which I connect to developments in book publishing and the end of the Cold War. Second, I identify common generic formal and structural aspects and analyze the content of a number of representative alternate history novels, which feature a libertarian combination of antistatism and militarism. Finally, I situate these increasingly popular books in their historical and political context and argue that they can be viewed not only as a marginal genre of popular fiction but also as a bellwether of mainstream American politics.

In many ways, this is exploration of uncharted territory. Both alternate historians and the few academics who have studied the phenomenon have attempted to ground the nascent genre by searching their libraries for similar texts, thereby creating a retroactive catalog of alternate history novels. ${ }^{8}$ While Livius' Ab urbe condita and Benjamin Disraeli's Alroy may share the (few) formal characteristics of contemporary alternate history novels, their inclusion in a master bibliography of alternate histories obscures the particular character of the genre that has recently emerged. ${ }^{9}$ When the generic formula of this popular formation is diluted by the addition of such diverse counterfactuals, its significance in its proper historical context is hidden. As Karlyn Kohrs Campbell and Kathleen Hall Jamieson put it, "the critic who classifies a rhetorical artifact as generically akin to a class of similar artifacts has identified an undercurrent of history rather than comprehended an act isolated in time." ${ }^{10}$ Since the early 1990s, hundreds of novels have attempted to re-imagine the past in various ways, and have engaged 
millions of fans - many of whom have become lay alternate historians of their own. ${ }^{11}$ How can we account for the contemporary explosion of alternate history as a literary genre? How is history being re-written, in what way, by whom, and why now? Before developing my own hypotheses, it will be necessary to further define the alternate history novel.

Some scholars have considered the alternate history to be a subgenre within science fiction, but this is misleading, since it can also take the form of a traditional novel or a work of fantasy. Although this article is concerned with literary counterfactuals, a number of films and television shows have engaged in counterfactual history, and one can argue that the increasingly popular video games with historical settings that allow for allohistorical developments should be placed in the same category. ${ }^{12}$ Despite the concept's flexibility there are important distinctions to be made. In his dissertation on the alternate history (which he calls "uchronia"13), William Joseph Collins makes the useful distinction between "pure uchronia," an alternate history in the form of a fictional work; "plural uchronia," alternate worlds that co-exist in literature; "infinite presents," a limitless amount of simultaneous distinct universes ${ }^{14}$; and the popular "time-travel alteration," where travel into the past creates a different present. ${ }^{15}$ My primary focus here is with the "pure uchronia," or, what Karen Hellekson has called the "true alternate history," which is often identified by its opposition to fantasy. ${ }^{16}$ While "true alternate histories" set in the distant past can lead to fantastic results- such as the evolution of intelligent dinosaurs in Brian Aldiss' The Malacia Tapestry - the goal of this genre is to create a universe that could plausibly exist today. ${ }^{17}$ No dragons or asteroids allowed. The alternate history is primarily an American phenomenon; almost two thirds of Sidewise winners or runners-up are American, and the most popular topics deal with themes directly relevant to U.S. history, often in an intentionally nationalistic manner. Judging from their web presence, the vast majority of alternate history fans are Americans. ${ }^{18}$ As a result, I examine the alternate history in the context of American politics and culture.

How can we explain the rise of the alternate history genre in the mid-1990s? Before introducing my own theory I will evaluate some of the most popular explanations provided by journalists and critics.

\section{The Nuts and Bolts of the Genre Machine}

In the early 1990s, the alternate history grew from a marginal category to a mainstream genre in the United States. Publishing industry statistics that would accurately measure the growth of the genre are not available, but a number of qualitative extrapolations can serve as approximations. A major sign is the critical attention the genre has received. By the turn of the millennium many national newspapers and magazines had published at least one article about the alternate history, most of them focusing on its very popularity. ${ }^{19}$ Academics have taken note: two books have been published and five dissertations completed in the last fifteen years. ${ }^{20}$ Another sign is the creation of an official publishing category; 
while most publishers continue to categorize alternate histories as "literature" or "science fiction," a number of smaller presses have acknowledged a devoted audience by creating a separate alternate history or alternate universe category. ${ }^{21}$ In addition, by the mid-nineties the novels themselves assume their readers' familiarity with the idea of a literary counterfactual. As one observer noted, alternate histories in the seventies and eighties "tended to present the concept of a novelist's changing history as itself a striking idea - which is an indication of how modestly the popular articles and genre fiction had penetrated general public awareness." 22

Finally, one can point, if only anecdotally, to the enthusiasm of many of the genre's readers. In 2002, David Dale in the Australian Sydney Morning Herald called the alternate history phenomenon not just a "growing branch of literature" or "controversial trend in scholarship" but a "passionate cult on the Internet." 23 The internet has facilitated affective investment by allowing fans to connect to each other - and thereby register their interest publicly—not just on online forums or fan sites like "AlternateHistory.com" and "Timelines-This Day in Alternate History" but via user-created sites such as Amazon Listmania! As of March 2011, Amazon displayed over 800 lists with "alternate history" in their title. ${ }^{24}$ In addition, the minimal formal regulations of the counterfactual experiment lead many readers to become writers (if unpublished) and create their own historical scenarios. As the alternate history has gone mainstream, the passion and size of its base has grown.

While there has been little systematic analysis of the genre's growth, several journalists and academics have suggested possible explanations. A number of reasons, such as revolutions in twentieth-century science and the influence of the entertainment revolution, have been debunked elsewhere. ${ }^{25}$ Aside from the impact of the end of the Cold War, which I will focus on, two factors deserve mention. The genre's connection to postmodernism has drawn the most attention, but developments in book publishing have played a more significant role in its growth.

The most widespread explanation for the growth of the alternate history is the influence of postmodernism on history and historiography. ${ }^{26}$ The salient features of postmodernism here are its ironic relationship to history; skepticism of traditional historical narratives, especially grand narratives; and privileging of alternative voices. For many critics, postmodernism is taken to be both a vague global trend as well as a historical event (a material cause, like a legislative act). ${ }^{27} \mathrm{In}$ its denial of the possibility of objective knowledge of the world and its emphasis on the role of subjectivity and narrative in historiography, postmodern thinkers claim, as one historian put it, that

Fictional stories invented by writers and the narrations fashioned by historians do not differ from one another in any essential respect because both are made out of language and 
equally subject to the latter's rules in the practice of rhetoric and the construction of narrative. ${ }^{28}$

The suggestion is that since postmodernism has knocked the historian from her perch, what we call history is not indistinct from literature. In postmodern historiography, then, the alternate historian has the same claim to truth as the academic.

Although this argument may hold some water in general, the mystery that surrounds the meaning of "postmodernism" makes it a somewhat facile and incontrovertible explanation. More importantly, it does little to explain the growth of the alternate history genre. Alternate history novels may have the attributes of postmodern texts but they do not function as postmodern histories for their readers and writers. Some scholars assert that postmodern texts fundamentally challenge - and, indeed, alter - the popular conception of the past so as to call into the question the very possibility of history and truth. But as one reviewer observed,

The genre does nothing that historians are not doing everyday, but it does provide a solid unchanging history, in its own way. The author of the alternate history sets in stone the change (s) he wishes to make in out accepted history. From that point on until every copy of the novel or short story vanishes, that particular view of history is permanent, after a fashion. From this perspective, alternate history appears to offer a solid stable ground for our history, rather than causing our foundations to slip away. ${ }^{29}$

Rather than provide a conflicting version of a dominant historical reading - as "history from below" does, for example - and thus challenge the foundation of historical objectivity, alternate histories tend to tell a different story in a traditional way. Alternate histories reinforce traditional western notions of historiographical objectivity even as they appear to subvert them.

If the birth of this curious genre owes a debt to postmodernism, it is more to the influence of postmodernism on the literary world. ${ }^{30}$ While postmodern literature generally refers to formally complicated serious literature produced by and for cultural elites, ${ }^{31}$ major postmodern theorists such as Jean- François Lyotard, Jean Baudrillard, and Frederic Jameson have argued that there is a postmodern influence on every aspect of culture, both high and low. Popular music, film, television, art and the media have all been influenced by postmodernism, and many elite postmodern texts have become remarkably popular. ${ }^{32}$ Whatever its effects on popular conceptions of history, it can certainly be argued that the blurring of categories, disciplines, and genres associated with postmodernism has paved the road for the popularity of alternate history novels.

Recent changes in the book publishing industry, however, have had a stronger and more direct role on the popularity of the alternate history genre. As Janice 
Radway noted in her classic study of romance readers, the dedicated fans of genre fiction allow booksellers to predict future sales reliably, satisfying the bottom lines of publishers and large chain bookstores..$^{33}$ Thus, the formation of genres is encouraged by the economic motivation of media institutions, and the alternate history is in some ways in a better position than other genres to benefit from the competitive marketplace. Gregory Feeley, a journalist and alternate historian, notes that,

The pressures of modern publishing have also helped, as alternate histories lend themselves almost uniquely well to what publishers call "high concept." The central idea behind most alternate histories is so straightforward as to be iconicsometimes conveyed in the title, but often reducible to a single image, which publishers have been happy to employ. ${ }^{34}$

In an oversaturated market book covers are designed to advertise the book, and iconic alternate history book covers are unusually descriptive of their content. ${ }^{35}$ For example, the cover of the 1997 Del Rey edition of How Few Remain: A Novel of the Second War Between the States has a confederate and an American flag crossed to form an $\mathbf{X}$, with the title and author's name in WANTED-poster Western letters and the corners singed, promising the shoot-'em-up military showdown between two regions that it eventually delivers. The cover of the 1997 Harper Voyager paperback Voyage has a massive American flag in the foreground and a small rocket shooting upward in the distance, which also heralds its patriotic tale of John F. Kennedy's backing of an American trip to Mars during his second term. As one of the few Sidewise winners to be issued by a small publisher and remain relatively unpopular, Martin J. Gidron's The Severed Wing is the exception that highlights the rule; while its cover is arresting (due to the Nazi insignia and the teardrops of blood), it gives little indication of the novel's plot. ${ }^{36}$

\section{The Liberation of Post-Cold War Historical Imagination}

Contemporary true alternate histories have tackled a wide range of imaginative subject matter, but the Cold War has been noticeably absent. This is, in part, because it does not easily fit the genre's formula: alternate historians tend to focus on the turning points or junctures of history, hot wars such as the American Civil War and World War II. While the possibility of a Soviet victory dwindled in western eyes during the 1980s, the continued ideological hegemony of one (if not both) of the dueling deterministic philosophies (Marxism and liberal capitalism) seemed inevitable until 1989. The Cold War paradigm continued to exert a powerful influence on Americans at least until the Berlin Wall actually fell. The cultural influence of the Cold War is often seen as limited to the hysteria of the 1950 s (bomb shelters, apocalyptic films, etc.), but recent historical scholarship is 
challenging that perspective by linking subjects such as the American family and the civil rights movement to the Cold War. ${ }^{37}$ It is, of course, impossible to draw a firm causal link between a historical event and a shift in the consciousness of an entire nation of diverse classes, races, ethnicities, religions, and genders, but it would be myopic to ignore the connection between the end of the Cold War and the growth of the alternate history.

The standoff between the Soviet Union and the United States was couched, by both superpowers, as an ideological battle between communism and capitalism. Many crucial aspects of American culture and society—such as the ideology of liberal capitalism and the dominance of neoclassical economics - were manipulated in Manichaean opposition to their Soviet counterparts. But if the American way was considered the antithesis of godless communism, both ideologies were confidently deterministic. The Soviet Union officially endorsed Marx's dialectical theory of history, which viewed capitalism as a necessary stage of historical development before communism. If Westerners were not quite as certain of the inevitability of their creed, their ideology was similarly teleological. The version of American liberal capitalism that emerged in the 1950s - a highly militarized welfare state founded on principles of secularism and individual liberty, governed by a representative democracy - was considered to be an ideal state of economic and social development that guaranteed timeless natural rights. While many citizens of the Soviet Union and its satellite states became disillusioned with Soviet communism, the vast majority of Americans continued to support-and had a deep affective investment in - what they considered the basic principles of the west, even if they increasingly objected to their application.

It would be impossible to measure the extent to which this ideological battle affected the consciousness of Americans over a period of four decades, but in many ways the post-Cold War period was more likely to produce anti-determinist narratives than its initial phase. In the 1950s and early 1960s, the Cold War was not only at the core of American foreign (and sometimes domestic) policy but also a presence in daily life. More than a framework to interpret the world, the Cold War guaranteed the future; the options available were communist subversion, a Soviet nuclear attack, an American victory, or a continued stalemate. As Alan Nadel writes in Containment Culture, ". . . the American Cold War is a particularly useful example of the power of large cultural narratives to unify, codify, and contain - perhaps intimidate is the best word - the personal narratives of its population. ${ }^{\prime 38}$ From the late 1950s through until the rise of détente in the mid 1970s, this narrative was enervated by domestic cultural and political movements. As the Baby Boom Generation grew into adolescence, youth culture and rock and roll music gave American parents something new to fear. For many Americans, the Civil Rights Movement replaced the threat of communism as the bogeyman of the decade. By the late sixties and early seventies, anti-war protests, Black Power, and the women's liberation movement seemed to have a greater influence on domestic culture than the Soviet Union. 
The period of détente, ranging roughly from 1972-1979, saw the normalization of a polarized world. ${ }^{39}$ In the wake of the "world revolutions" of 1968, elites on both sides of the Iron Curtain sacrificed idealism for stability. As Cold War historian Jeremi Suri put it,

The 'peace' created by détente entrenched the social and political status quo. Cooperation among the great power became a substitute for both domestic and international reform. . . . Diplomatic arrangements made war less likely, but they also froze most of the initial sources of antagonism in place. ${ }^{40}$

In the 1970s, the Soviet Union and the United States reconciled themselves to accepting a world that was divided along political and ideological lines. During the 1950s, many Americans expected a hot war to change their world, one way or another. By the 1970s, with the ambitious political aspirations of the late sixties frustrated and a foreign policy designed to preserve the status quo, change seemed much less likely. After the minor flurry of Nazi-inspired allohistories published in the 1950s and 1960s, such as Philip K. Dick's The Man in the High Castle, comparatively few American alternate histories were published until the 1990s.

The end of détente is attributed to increased open conflict in the Middle East and the election of Ronald Reagan. As historian John Lewis Gaddis put it,

[Reagan] saw that the Cold War itself had become a convention: that too many minds in too many places had resigned themselves to its perpetuation. He sought to break the stalemate-which was, he believed, largely psychological—by exploiting Soviet weaknesses and asserting western strengths. ${ }^{41}$

Reagan pursued this end through confrontational rhetoric, an emphasis on military technology, and aggressive diplomacy. If, in retrospect, we see Gorbachev's policies of glasnost and perestroika as the beginning (or sign) of the end, most Westerners at the time did not. The division of the world into two oppositional camps - even if one of them seemed to be dwindling and crumbling - had been normalized for almost a half-century. As a result, Gaddis noted that "the upheavals of 1989 , like those of 1789 , caught everyone by surprise." 42

The end of the cold war had a powerful effect on authors and audiences alike. The collapse of the Soviet Union coincided with a shift in the literary career of the alternate history genre's most prolific writer, master of alternate history Harry Turtledove, whose popularity is so great that no small portion of genre's emergence and success could be placed on his shoulders alone. Turtledove received a PhD in Byzantine history in 1977 and immediately published his first novel, Wereblood, the first novel of a fantasy series set in the ancient Byzantine era. ${ }^{43}$ Between 1977 and 1991, Turtledove published twelve novels, ${ }^{44}$ most of them either fantasy or science-fiction. His first alternate history was Guns of 
the South, published in 1992. While he continues to publish fantasy novels and short stories, Turtledove has become the face (or name) of the alternate history genre. He has published three separate, unrelated alternate histories of the Civil War. ${ }^{45}$ Despite a decade-long literary career, Turtledove did not begin to re-write American history until the Cold War permanently thawed.

New possibilities emerged. For most alternate historians, the plausibility of the alternate timeline is of great importance. Many authors argue in the first person for the historical accuracy of their literary counterfactual; for them, alternate histories are not so much what-if but almost-was. In his introduction to 1862, Robert Conroy claims that "the possibility of England entering the war on the side of the Confederacy was very real" ${ }^{\prime 46}$; Michael Chabon's The Yiddish Policeman's Union and Philip Roth's The Plot Against America both contain afterwords with detailed, supportive historical documentation. ${ }^{47}$ Stephen Baxter, in the Author's Note accompanying Voyage: A Novel of What Might Have Been, goes one step further.

In 1996, we need scientists on Mars. They could have been there a decade ago. My novel may be the closest thing to a history of that lost, alternate universe ever to be written, and I have striven to make it as "true" as possible.

It really would have been like this. ${ }^{48}$

Sometimes these claims of historical objectivity are matched by reviewers: $P u b$ lishers Weekly's review of How Few Remain, printed on its inside cover, praises Harry Turtledove for his "rigorous historiography" in a novel that portrays a gentlemanly conversation between Frederick Douglas and Stonewall Jackson behind Confederate lines. At the end of the Cold War, the plausibility of such a historical mutation was increased due to the loosening of the hegemonic hold of deterministic ideologies in the United States. The increased flexibility of retroactive imagination is underlined by the mutation of another historical figure in How Few Remain: the proud socialist and disgraced president, Abraham Lincoln.

\section{The Character of the Contemporary Alternate History}

The alternate history is undoubtedly a genre, but unlike the romance novel, the western or the thriller, the various forms the contemporary alternate history assumes defy easy categorization. Alternate histories have been written as spy thrillers and fictional autobiographies, mysteries and historical novels. A generalization, even confined to the true alternate history in the last decade and a half, will overlook dozens of counterexamples. Nonetheless, there are a number of commonalities among the majority of alternate histories, especially those that have become most popular, which provide a window into the broader cultural significance of the genre. Journalists and academics searching for the message of individual alternative histories have tended to investigate the surface moral 
and ethical significance of each novel's plot—Does this author condone the South winning the Civil War? How do they portray Hitler? - while missing the political arguments implicit in the structures and shapes of the alternate worlds presented in each novel. Very few commentators have subjected the alternate universes in this genre to the kind of political analysis that is applied to some science fiction, for example. ${ }^{49}$

The two bedrock features of the alternate history are its emphasis on military and physical force as the prime movers of history and, counterintuitively, a deepseated distrust of centralized government, even extending to the military itself. In her essay "Genre as Social Action," Carolyn Miller identifies three layers of generic elements, the "substantive, stylistic, and situation," which she equates to content, form, and context. Miller sees the three in a hierarchical relationship, and using this framework we can articulate why many casual observers have not identified this genre's structural elements. Journalists have often considered only the genre's substance (the setting, characters, and plot of each novel); others have considered the form of the alternate history and the counterfactual; but very few have assessed its context. While Miller uses context to describe the "speech-act[s]" of the alternate historians themselves, I want to extend that term to the context of the characters in each novel: the political, social, and cultural shape of the universe they inhabit. It is necessary to identify and juxtapose the contexts of the authors and their characters in order to understand the alternate history as a cultural formation. ${ }^{50}$ Under this spotlight, the alternate history reflects the power of libertarian thought in the contemporary United States.

In their selection of a point of departure, each alternate historian implicitly endorses a theory of historical change. With a few notable exceptions, alternate historians support the great man theory or the primacy of military action, if not both. To survey the genre as a whole I look to the Sidewise Awards. From 1995 to 2007, 44 novels were selected as winners and runners-up of the Sidewise Award for Alternate History. ${ }^{51}$ Of these, 29 can be considered true alternate histories. ${ }^{52}$ While this may constitute a small sample size, it is useful to highlight some trends that continue outside of the winner's circle. In 24 out of the 29 , the point of departure is either a different outcome of a military confrontation or a decision made by a powerful (and still well-known) individual. ${ }^{53}$

The "great man" theory of historiography is associated with nineteenthcentury philosopher Thomas Carlyle, who claimed that "[t]he history of the world is but the biography of great men." ${ }^{, 54}$ Today the great man theory informs thick biographies of presidents, scientists, and historical figures; in the twentyfirst-century American culture of celebrity (and the imperial presidency) it is almost common sense. Many authors, such as Turtledove and Robert Conroy, see famous individuals as possessing an almost superhuman will-to-power that destines them to rise to fame regardless of their circumstances; sections read like historical fiction, with long debates and confrontations between generals and presidents that test the boundaries of plausibility. ${ }^{55}$ For example, the point of departure in Gidron's The Severed Wing is Theodore Roosevelt's third term, 
but the actress Susan Sarandon still works her way into the public's eye - as Vice President of the United States. ${ }^{56}$

The second theory endorsed by most contemporary alternate histories is that of military history, which claims that military battles are the most significant and influential historical events. They are turning points, moments of bifurcation, whose consequences fundamentally determine the character of the world for decades, centuries, or even millennia. While many alternate histories include detailed military battles, most of them do not. They differ from military fiction in that they simply mention that the point of departure, decades before the novel's present, involved an alternate military outcome. Most contemporary alternate histories portray worlds that are dominated by the preparation for, waging of, and consequences of war - the two most popular themes in the genre are a Nazi victory in World War II and a Confederate victory in the American Civil War.

Often, the fulcrum is both personal and military. In How Few Remain, a tactical error by Abraham Lincoln leads to the North's defeat in the first Civil War. Brendan DuBois, in Resurrection Day, has John F. Kennedy accidentally engage the Soviet Union in a nuclear war that destroys both nations. Pamela Sargent's Climb the Wind envisions a Native American named Touch-the-Clouds uniting indigenous Americans to resist militarily the United States in the decades after the Civil War. If these points of departure seem like natural choices, their limited range is brought into relief by the few alternate histories that rely on different points of departure, such as The Age of Unreason. In this four-part series, beginning with Newton's Cannon in 1998, the point of departure is seventeenth-century science. Instead of Newtonian physics and the scientific method, the scientific paradigm that dominates the novel's world is closely tied to religion, spirituality, and alchemy. This leads to an alternate world that is fundamentally different in almost every conceivable way. ${ }^{57}$

The abuse of power and mobilization of the industrial state for nefarious purposes is the most glaring and perhaps universal feature of the contemporary alternate history novel. In the 24 novels I have identified, the military has a palpable presence that saturates the imaginary world but often fails to guarantee safety, not unlike the arms race during the cold war. If the Nazi state provides the referential model, the unstated goal of many alternate historians is to show that wholesale political corruption, if not totalitarianism itself, is always right around history's corner - not only can it happen here (usually referring to the West), it almost did. ${ }^{58}$ In Philip Roth's The Plot Against America, Charles Lindbergh defeats Franklin Delano Roosevelt to become president in 1940 and (after establishing an alliance with Hitler) uses the machinery of the federal government to murder American Jews. ${ }^{59}$ In Time On My Hands, President Ronald Reagan's abuses of executive power motivate a travel writer and physicist to travel back in time and derail his political career. In The Yiddish Policemen's Union, the President helps a radical Jewish sect bomb Palestine and ignite a global holy war so as to expedite the Christian Apocalypse. One character's lamentations could summarize the conspiratorial mood of many alternate histories: "God damn 


\section{Matthew Schneider-Mayerson}

them all. I always knew they were there. Down there in Washington. Up there over our heads. Holding the strings. Setting the agenda. Of course I knew that. We all knew that." ${ }^{\circ 0}$ Even outside of the novels that focus on a victorious Nazi Germany, the genre's emphasis on institutional racism, ${ }^{61}$ military treachery, ${ }^{62}$ and government censorship ${ }^{63}$ can be highlighted by a comparison with science fiction. Although many sci-fi writers have explored dystopian futures, the genre has often displayed a utopian optimism in the possibility of political, social, and technological progress enabled by a massive (even global) centralized government. ${ }^{64}$ Most contemporary alternate histories, on the other hand, have viewed big government as a threat with few benefits.

With these thoughts in mind, I want to look in depth at one representative novel: Brendan DuBois' Resurrection Day. It won the Sidewise Award in 1999 and makes explicit themes that are implicit and assumed in many alternate histories. Resurrection Day is set in 1972, ten years after a global nuclear war that followed the Cuban missile crisis, the novel's point of departure. America's large cities, infrastructure, military, and civilian leadership were devastated by Soviet bombs, while America's nuclear weapons destroyed the Soviet Union. The twin plot lines of the novel surround the missile crisis and the military. The accepted history of the missile crisis blames President Kennedy for recklessness, but Resurrection Day's protagonist, Carl Landry, discovers that a top army official (a General Curtis) actually ordered the strike on Cuba. In the ensuing decade, Curtis has maintained a military dictatorship by repressing political resistance and censoring the press.

Landry is at the center of Resurrection Day. Within the novel he functions as a reporter, but his military history often foregrounds the action. As a "goddamn quota baby" rewarded for his post-nuclear service, Landry holds a job for which he is unqualified. ${ }^{65}$ The barbs he receives from his colleagues speak to the wall between soldiers and civilians in the novel, which reflects the experience of American soldiers after the Vietnam war and the political division between hawkish conservatives and somewhat less militaristic Democrats. At the same time, as the narrator repeats time and time again, Landry's survival in the face of a government conspiracy to assassinate him is due to his background in the armed services. He calls on the mental, physical, and technological skills that he learned during military training and service to protect himself from the government that trained him - a fitting metaphor for the ideological contradictions of the genre itself. For example, as he hides from army snipers,

Carl emptied one of the two satchels into his knapsack and fastened the blankets to the pack. He pulled out his holstered Colt .45, unbuckled his belt, and slipped the holster onto it. Sandy stared at him, and then the weapon.

"Where did you get that?"

"From my years of service to this country, that's where. ${ }^{66}$ 
The dedication to this paradoxical position is apparent in DuBois' inability to imagine a radically different alternative to his dystopia. In his search for the historical record of Kennedy's valor, Landry makes his way through the underground world of officially abandoned post-nuclear New York City. But instead of a pacifist, egalitarian community, might-makes-right even in this romanticized resistance and power is just as centralized below as it is above. As such, the leader of the PS 19 gang and the mayor of underground New York is seen as a king:

It was like young royalty, he thought, moving among his people. They went into a dark part of the subway station, past another barricade where a couple of young men were sitting, holding what looked like police revolvers in their hands. ${ }^{67}$

The culture of these revolutionaries imitates the militarism, hierarchal organization and conflicted commitments of the world above.

The unspoken tension between the lionization of the military and a distrust of centralized government that is at the heart of Resurrection Day and many contemporary alternate histories should be viewed in light of similar tensions within American conservatism. The politics of a genre as diverse as the alternate history are not immediately apparent in the arena of ethics or values, what Miller calls the "substance" of each novel. By situating the contemporary alternate history within the historical context of its production and consumption, the ideological commitments that inform the genre become clear: a libertarian distrust of "big government" on one hand and a dedicated militarism on the other. As the alternate history took shape in the mid-1990s, it reflected the political philosophy that had been re-calibrating the American political landscape for over a decade.

\section{The Growth of Libertarianism in the United States}

Modern conservatism emerged on the national stage with the election of Ronald Reagan in 1980 after two decades of gestation. The conservative movement has been covered extensively by historians in recent years, but its relevance to my subject requires a brief summary here ${ }^{68}$ The growth of the right was initially the result of a widespread backlash against the liberalism of the 1960s, but it developed through decades of grassroots conservative organizing. The pillars of the ideology that emerged were "an antistatist libertarianism and a normative conservatism" that found an increasingly receptive audience in the 1970s, especially among whites and suburbanites ${ }^{69}$ Social conservatism was tied to a perceived moral permissiveness in the wake of the Vietnam War and the various political movements of the 1960s and 1970s, which provoked a renewed desire for traditional family values; the libertarian element was the result of extreme ideological polarization encouraged during the Cold War. With the Soviet Union in mind, many Americans saw the muscular liberal state that emerged in the 1960s-Lyndon Johnson's Great Society, federal legal protection against race 
and gender discrimination, and above all the welfare state - as an encroachment on personal liberty. In this sense libertarianism drew on the traditional American mythology of western, rugged individualism.

Ronald Reagan wedded conservative and libertarian ideas to a patriotic populism. Reagan's passionate rhetoric against big government, taxation, and the welfare state effected a lasting influence on American politics by moving social conservatism and libertarianism into the mainstream. Even after Reagan and George H.W. Bush were out of office, the power of libertarian ideas remained. The Wall Street Journal noted in 1995 that,

Because of their growing disdain for government, more and more Americans appear to be drifting - often unwittinglytoward a libertarian philosophy. That seems particularly true among baby boomers returning to the "do your own thing" ethos of their youth and among young people involved in the intensely independent computer industry. Indeed, when the Gallup polling organization last year asked questions about government's role that were designed to distill Americans' political philosophies, it categorized $22 \%$ of the public as "libertarian."

In his 1996 State of the Union address, Bill Clinton acknowledged the continuing popularity of antistatism by claiming that "The era of big government is over."

The meteoric rise of alternate historian Newt Gingrich checked the liberal (if not leftist) tendencies of the Clintons, and briefly led observers to believe that a more overt form of libertarianism might emerge. In 1995 USA Today announced (with some hyperbole) that "what liberalism was to the "60s and conservatism was to the " $80 \mathrm{~s}$, libertarianism may be to the youth of " $90 \mathrm{s."}$ " 72 In 1994 Gingrich, along with other Republican congressmen, published Contract With America, with its emphasis on tax cuts and welfare reform. That November, Republicans gained 54 seats in house elections; Gingrich became the first Republican speaker in 40 years, and in 1995 Time named him their Man of the Year. ${ }^{73}$

At the same time as Americans were pushing for less government, they were investing more money and faith in the military. The depth of the "new American militarism," as historian Andrew Bacevich has called the phenomenon, goes far beyond military expenditures. ${ }^{74}$ In the wake of the Vietnam War and the resulting national distrust of the armed forces, Reagan set out to restore military confidence by mythologizing the American soldier and constructing the military as a weathervane of national strength. The symbolic manipulation was, in part, the groundwork for actual increases in defense spending (which doubled during Reagan's presidency ${ }^{75}$ ), but it had cultural effects that lingered until very recently. After the apparent success of the Gulf War, military expenditures and the deification of the armed forces only increased, as Democrats such as Bill Clinton found it politically suicidal to question the new American militarism. 
Since the end of the Cold War, opinion polls surveying public attitudes toward national institutions have regularly ranked the armed services first. ${ }^{76}$ While confidence in the executive branch, the congress, the media, and even organized religion has waned, confidence in the military continues to climb, as reflected in the majority of alternate histories. ${ }^{77}$ Even apart from Turtledove-style novels that could double as military fiction, ${ }^{78}$ many alternate histories see military battles as history's turning points. Perhaps diplomacy does not sell.

The apparent contradiction between a libertarian distrust of big government and an embrace of the armed forces that represent that government is a cognitive dissonance that did not troubled modern American conservatism until the mid-2000s, when the alliance between economic and religious conservatives that elected and re-elected George W. Bush unravelled. In the reality of facts and figures, this equation has created massive debt for the United States; in the world of popular culture, the result is a character like Resurrection Day's Carl Landry, who owes his survival to his military training as he is hunted by his own government.

\section{Conclusion}

To suggest a link between alternate history novels and conservative politics is not to claim that Turtledove, Conroy and Roth are dedicated libertarians who use their fiction as an ideological tool. In fact, there is a wing of science fiction which is explicitly libertarian. In 1980, L. Neil Smith, the founder of the Prometheus Award for Best Libertarian Fiction, published The Probability Broach, a plural uchronia where a single altered word in the preamble to the Declaration of Independence leads to a revolt during the Whiskey Rebellion and the execution of George Washington. Two hundred years later, the United States is a libertarian paradise without a functional central government; men, women, and even children arm and defend themselves. The subtler libertarian coloring of the alternate history does reflect the politics of its authors, though in a less deliberate and direct way.

Alternate histories have often been seen as thought experiments, with each author a scientist who spins the wheel of chance without bias or partisanship. But, to run with this metaphor, each novel betrays the wheel's tilt and its direction. That most alternate history novels are considered apolitical reflects the extent to which the principles of libertarianism have oriented the naturalized, national political paradigm. In the spirit of the alternate history, one might ask, What if the genre had existed twenty years ago? How would the worlds of these novels differ? Psychologists who have studied the mechanics of counterfactual thinking have noted that counterfactuals tend to betray the limits of imagination:

[T]he likelihood of a person's mentally mutating salient events, exceptions, and actions is a function of the ease with which these events come or are brought to mind, relative to other 
events... That is, if it is difficult for one to imagine alternatives to an event, that event will not be mentally mutated. ${ }^{79}$

From this perspective, we can see the alternate history genre not as a marginal subculture that appeals only to science fiction geeks and libertarians, but an unconscious cultural reflection of the political zeitgeist of mid-1990s America. One way to test this hypothesis is to search for anti-libertarian alternate histories, where centralized government is viewed in a positive, optimistic or even utopian light. Of the 29 novels in my sample, only two, Disturbance Of Fate and Voyage, are in the ballpark. ${ }^{80} \mathrm{~A}$ deeper detour into the various ways that alternate histories could be written would only further de-naturalize the genre's character.

Future research on alternate history novels should focus on their producers and the meanings created in their consumption. Who are these alternate historians? 34 individuals have won the Sidewise Award or received an honorable mention. ${ }^{81}$ Of these, 28 are men, 6 are women; 24 are American and 10 are European; every novelist to receive an award or honorable mention appears to be (what according to the dominant contemporary American racial formation would be characterized as) racially white. The connection between the worlds created by this overwhelmingly white, male group can be contrasted with the few black authors who have written in this genre. African American author Steven Barnes, for example, has published two books in an alternate history series, Lion's Blood and Zulu Heart, in which America was colonized by Islamic Africans from Egypt. In his alternate America, "Bilalistan," racial hierarchies are reversed, with Africans and Arabs in positions of power while European slaves are used for manual labor. ${ }^{82}$ The connection between Barnes' race, gender, and nationality and his fictive world has been widely noted, ${ }^{83}$ but the role that the same factors play for white, male, American writers who compose the majority of alternate histories is ignored.

Audience research would be extremely useful to understand how readers make sense of the genre and how it influences them. As Edward Schiappa argues in Beyond Representational Correctness, in her reception of a text each individual creates a "phenomenal text" which is "the text as its various readers perceive and experience it." ${ }^{84}$ In this paper I have focused on the texts themselves, with the understanding that alternate histories are made to "mean" something new by each reader. The profile of the alternate history reader has not been studied to date. Further research on this subject will hopefully take into account not only the socioeconomic status of writers and readers but also the relationship between the two. The role of this genre in performing the cultural and ideological work of influencing readers is unfortunately beyond the scope of this paper, but the contemporary alternate history's ability to encode dominant political positions within a marginal genre of popular fiction certainly leaves that possibility open.

Viewed in its historical context, the alternate history is far from the apolitical literary exercise in historical contingency that it appears to be. Its emergence can be tied to specific historical and political circumstances, and the shape of its internal worlds - which readers are invited to perceive as likely alternatives 
to actual historical development - should be seen in as a reflection of the influence of libertarianism on contemporary American political thought. The genre's longevity and popularity will ultimately depend on a host of factors, but one of them is undoubtedly its reaction to changes in the American political and social climate, since the generic conventions that shape literary consumption are best understood as constantly in flux, "undercurrent[s] of history rather than ... isolated in time." The alternate history novel and various manifestations of counterfactual thought present an interesting opportunity for future research, especially as the United States undergoes what appears to be significant political changes. As I have argued by viewing the rise of the genre in the context of the cold war, the alternate history is not just, as some critics argue, about re-writing history, but a test of the limits of historical imagination. If indeed there has been or will be an expansion in the popular or national imagination of what is possible, counterfactual literature may serve as one canary in the coal mine.

\section{Notes}

1. Newt Gingrich, To Renew America (New York: Harpercollins, 1995); Contract with America was released during the 1994 congressional campaign and can be viewed in full at $<$ http://house. gov/house/Contract/CONTRACT.html> accessed on May 30, 2011.

2. Newt Gingrich and William R. Forstchen, 1945 (New York: Baen Publishing, 1995).

3. Two exceptions are Joan Didion, "The Teachings of Speaker Gingrich," The New York Review of Books, August 10, 1995, later published in Political Fictions (New York: Alfred A. Knopf, 2001); and H. Bruce Franklin, "Only the Hardware is Erotic," The Nation, August 14/21, 1995.

4. Gavriel Rosenfeld, The World Hitler Never Made: Alternate History and the Memory of Nazism (Cambridge: Cambridge University Press, 2005).

5. The definition of "genre" is, of course, highly contested. Without engaging in too lengthy an entry into the long scholarly discussion over how genre is defined, I believe, for reasons to be explored later, that the identification of a genre is useful as a means of critical analysis. Although I do give producers (and marketers) as well as readers a significant role in establishing and shaping the genre of alternate history novels, part of the explanation for its emergence as a genre is a pattern of rhetorical similarities. As a baseline definition I quote Karlyn Kohrs Campbell and Kathleen Hall Jamieson, who claim that "a genre is composed of a constellation of recognizable forms bound together by an internal dynamic." "Form and Genre in Rhetorical Criticism: An Introduction" in Form and Genre: Shaping Rhetorical Action, eds. Campbell and Jamieson, (Falls Church, VA: Speech Communication Association, 1978), 21.

6. The Sidewise Award website, <http://uchronia.net/sidewise/> (accessed may 30, 2011), lists the names and addresses of the current judges but does not list the evaluative criteria they apply, nor the reasons for their selections.

7. After a thorough search of the most popular alternate history fan site, www.alternatehistory.com, I found many references to the Sidewise Awards but very little second-guessing of their choices and no criticism of the institution itself. 1,029,374 posts were searched on Thursday, January 15,2009 . Since my search was conducted only in English, I do allow the possibility that readers outside of the United States consider the Sidewise Awards to be an unfairly Anglo-centric award but that I am unable to read and take notice of their criticisms. However, while such a criticism would demand a qualification in the name of my subject - "American alternate history novels" would be more accurate - it would not invalidate the connection between the genre and American events and politics.

8. For example, Cynthia Crossen, “'What Ifs’ Don’t Thrill Historians, but They Raise Intriguing Issues," Wall Street Journal, February 2, 2005; Karen Hellekson, "Toward a Taxonomy of the Alternate History Genre," Extrapolation, 41 (Fall 2000).

9. Titus Livius, Ab Urbe Condita (New York: Penguin, 2002); Benjamin Disraeli, Alroy: The Prince of the Captivity (Middlessex: Echo Books, 2007). This is not to say that alternate history novels did not exist before the 1990s. As the entry on "Alternate Worlds" in The Encyclopedia of Science Fiction (eds. John Clute and Peter Nicholls, London: Orbit Books, 1999) and the website $<$ www.uchronia.org > mention, there were scores of counterfactual novels and stories published before the 1990s. Some of them deserve special mention here. Mark Twain's 1889 time-travel novel A Connecticut Yankee in King Arthur's Court is often considered a precursor to the genre, 


\section{Matthew Schneider-Mayerson}

and is an example of popular author's foray into counterfactual speculation; British historian J.C. Squires' 1931 collection If It Had Happened Otherwise (New York: St. Martin's Press, 1974) was a pioneering collection for both alternate historians and professional historians; "Sidewise in Time," the Murray Leinster short story which lent its name to the genre award, is considered a foundational classic (first published in Astounding Stories 13 (June 1934). More recently, Ward Moore's classic 1953 Civil War novel Bring the Jubilee (New York: Random House) developed one of the central themes of the genre; Philip K. Dick's brilliant The Man in the High Castle (New York: Random House) was an extremely influential work that won the Hugo Award for best science fiction of 1962. In addition, there are a number of science fiction novels that address time travel without necessarily altering the "present," such as Poul Anderson's Time Patrol series, and thus are often not considered as "alternate histories" per se.

10. Campbell and Jamieson, "Form and Genre in Rhetorical Criticism," 26.

11. Indeed, in researching the community of alternate history readers, one is struck by the fact that they seem to enjoy engaging in their own original counterfactual speculations as much if not more than they do discussing their favorite published works. Indeed, as mentioned above, the fundamental what if premise behind the genre taps into an elemental human interest in individual action and historical contingency. On January 12, 2007, the discussion forum for "Alternate History Books and Media" on <www.alternatehistory.com> had 3,069 posts; "Alternate History Discussion: Before 1900" and "Alternate History Discussion: After 1900" had 14,868 and 15,445, respectively. To give a sense of the sort of issues readers are concerned with, the three most recent posts were on the topics, "Could the Falklands War get Screwed Up?", "Possibly Different Gettysburg," and "Alternate Roles for Well Known People."

12. Although a few films such as It Happened Here (Directprs Kevin Brownlow and Andrew Mollo, United Artists, 1966) and the recent mockumentary C.S.A.: The Confederate States of America (Director Kevin Willmott, Hodcarrier Films, 2004) have engaged in counterfactual historical speculation of the type I am discussing here, films have tended to apply the concept to individual persons. Whether the proliferation of films such as Sliding Doors (Director Peter Howitt, Miramax Films, 1998), Run Lola Run (Director Tom Twyker, Sony Pictures, 1998), and The Butterfly Effect (Directors Eric Bress and J. Mackye Gruber, New Line Cinema, 2004) is related to the alternate history genre is beyond the scope of this article, although there does not seem to be a significant growth in the number of such films in the 1990s and 2000s. However, I would argue that there was a direct connection between the rise of the alternate history and the popularity of the television show Sliders, which ran from March of 1996 to December of 1999. Sliders presented a group of travelers moving around the "multiverse," from one version of the United States to another, with the sort of political, social, and cultural shifts that typically occur in alternate history novels. The connection between the alternate history and contemporary online gaming is thought-provoking; a number of exceptionally popular games over the last decade and a half have utilized the concept of historical contingency. To pick two examples that span the time period I am concerned with, in 1996 Command \& Conquer: Red Alert (Westwood Studios) depicts Albert Einstein travelling back in time to kill Adolf Hitler before he enters German politics; a decade later, the 2007 game World in Conflict is set in an alternate 1989, when desperate Warsaw Pact forces stage an assault on Western Europe and the United States. Whether a relationship can be drawn between the alternate history novel, Sliders and allohistorical online gaming - or whether the appearance and popularity of the latter two can be attributed to the same forces I identify here - is a fascinating question that deserves a more thorough analysis.

13. "Uchronia" is a portmanteau of "utopia" and "chronos," meaning time.

14. The best example of the "plural uchronia" is Sliders.

15. William Joseph Collins, "Paths Not Taken: The Development, Structure, and Aesthetics of the Alternative History," Unpublished PhD dissertation, University of California-Davis, 1990, 85-86. Collins' dissertation treats the alternate history as a subgenre of science fiction and fantasy; while it is useful for identifying categories within the genre, it was written before the contemporary true alternate history emerged as a cultural formation in the mid-1990s.

16. Hellekson, "Toward a Taxonomy," 251.

17. Brian Aldiss, The Malacia Tapestry (New York: Ace, 1976).

18. There has been little to no critical discussion among fans, writers, or scholars about the distribution of alternate history writers and fans around the world. In this article I use the Sidewise Awards as a barometer of the genre as a whole, but I am aware that this selection may very well be biased itself. It would certainly be incorrect to say that all alternate history writers and/or readers are American. There are alternate historians writing in a number of other languages, especially French, and many American alternate histories have been translated into dozens of languages. However, many of these "alternate histories" written in other languages for different audiences, though also organized around the what if question, do not belong in the genre I define because they do not follow the generic rules I identify. I would argue, however, that as a category of popular fiction that arose in the United States, with American writers and publishers and by all accounts intended for American readers, there is a basis for viewing the popularity of this particular genre as a distinctly American cultural formation whose implications can be read through a national lens. 
19. Gregory Feeley, “The Way It Wasn't: How what-if history grew from a minor literary curiosity to a bestselling genre of popular fiction," The Weekly Standard, September 6, 2004, Issue 48; Alessandra Stanley, "Selling the Alternate (But Not Too Alternate) Ending," The New York Times, December 15, 2002.

20. Two books on the alternate history have been published: Rosenfeld, The World Hitler Never Made; and Karen Hellekson, The Alternate History: Refiguring Historical Time (Kent, Ohio: Kent State University Press, 2001). The dissertations are Collins, "Paths Not Taken"; Ed Mcnight, Alternative History: the Development of a Literary Genre (University of North Carolina, Chapel Hill, 1994); and Jorg Helbig, Der Parahistorische Roman. Ein Literarhistorischer Und Gattungstypologischer Beitrag Zur Allotopieforschung (Freie Universitaet Berlin, 1987).

21. Del Rey books, for example. Del Rey is a subsidiary of Ballantine Books, which is owned by Random House.

22. Feeley, "The Way It Wasn't," 21.

23. David Dale, "If the losers had won. .., , Sydney Morning Herald, March 23, 2002.

24. <http://www.amazon.com/gp/community-content-search/results/ref $=\mathrm{cm}$ srch q col rpli $/$ ?query $=\% 22$ alternate + history $\% 22 \&$ search-alias $=r p-l i s t m a n i a \& x=0 \& y=0>$ accessed May $\overline{3} 0,2 \overline{0} 11$.

25. Rosenfeld, The World Hitler Never Made, 9.

26. Feeley, "The Way It Wasn't" and Rosenfeld, The World Hitler Never Made, for example, both cite postmodernism as having a causative influence on the rise of the genre.

27. Rosenfeld, The World Hitler Never Made, 7.

28. Perez Zagorin, "History, the Referent, and Narrative: Reflections on Postmodernism Now," History and Theory, 38, 1-24.

29. Brent Stypczynski, "No Roads Lead to Rome: Alternate History and Secondary Worlds," Extrapolation, 46 (Winter 2005), 453-470. Emphasis added.

30. Feeley, "The Way It Wasn't," 22.

31. Authors such as Thomas Pynchon, Don Delillo, and William H. Gass, for example. Jeremy Green makes a similar claim in Late Postmodernism: American Fiction at the Millennium (New York: Palgrave Macmillan, 2005), 5.

32. Barry Lewis, "Postmodernism and Literature (or: Word Salad Days, 1960-90)," The Routledge Companion to Postmodernism (London: Routledge, 2001).

33. Janice A. Radway, Reading the Romance: Women, Patriarchy, and Popular Literature (Chapel Hill: The University of North Carolina Press, 1984), page 37.

34. Feeley, “The Way It Wasn't," 22.

35. Tom Dickoff, "They’ve got it covered," The Guardian, September 15, 2001.

36. For some authors, the connection between story and image can even work backwards: the concept behind Harry Turtledove's The Guns of the South-right-wing Afrikaaners traveling into the past to arm the Confederacy with AK-47s - originated in a friend's complaint that the cover art for her novel was "as anachronistic as Robert E. Lee with an Uzi." Sheldon Teitelbaum, "Playing With History: Fantasy Writer Harry Turtledove Looks at the Past and Asks, 'What If. . ., ", Los Angeles Times, July 7, 1992.

37. For example, in Homeward Bound: American Families in the Cold War Era (New York: Basic Books, 1988), Elaine Tyler May argues that the structure of and emphasis on the family in the postwar period was not an escape from international politics but a highly political, integral aspect of the battle against Communism. In The Cold War and the Color Line: American Race Relations in the Global Arena (Cambridge: Harvard University Press, 2001), Thomas Borstelmann argues that racial relations within the United States must be understood in reciprocal relation to the cold war battle for the hearts and mind of third world nations, especially in Africa. In A Consumers' Republic: The Politics of Mass Consumption in Postwar America (New York: Vintage Books, 2003), Lizabeth Cohen claims that the rise of consumerism in the United States was, directly and indirectly, a response to Soviet collectivism.

38. Alan Nadel, Containment Culture: American Narratives, Postmodernism, and the Atomic Age (Durham: Duke University Press, 1995), 4.

39. Jeremi Suri, Power and Protest: Global Revolution and the Rise of Détente (Cambridge: Harvard University Press, 2003), 307.

40. Ibid., 217.

41. Gaddis, 222.

42. Ibid., 238.

43. Eric Iverson, Wereblood (London: Belmont Tower, 1979). Until 1985, Turtledove published under this pseudonym - according to legend, his editors at Belmont Tower doubted that readers would believe the authenticity of his real name.

44. Wereblood; Werenight (London: Belmont Tower, 1979); The Misplaced Legion (New York: Del Rey, 1987); An Emperor for the Legion (New York: Del Rey, 1987); The Legion of Videssos (New York: Del Rey, 1987); The Swords of the Legion (New York: Del Rey, 1987); Agent of Byzantium (New York: Congdon \& Weed, 1987); Noninterference (New York: Del Rey, 1988); A World of Difference (New York: Del Rey, 1990); Krispos Rising (New York: Del Rey, 1991); Krispos of Videssos (New York: Del Rey, 1991); and Earthgrip (New York: Del Rey, 1991). 
45. Harry Turtledove, How Few Remain (New York: Del Rey, 1997); The Great War: American Front (New York: Del Rey, 1998); The Guns of the South (New York: Del Rey, 1992).

46. Robert Conroy, 1862: A Novel (New York: Presidio Press, 2006), v.

47. Even so, neither Roth nor Chabon, by far the two most prominent Sidewise winners, has acknowledged their participation in (or even previous awareness of) the alternate history genre. 1996), i.

48. Stephen Baxter, Voyage: A Novel of What Might Have Been (New York: HarperPrism,

49. Classic science fiction writers such as Isaac Asimov, Ray Bradbury, and Philip K. Dick have been studied extensively. One representative example is David Seed, American Science Fiction and the Cold War (Edinburgh: Edinburgh University Press, 1999).

50. Carolyn R. Miller, “Genre as Social Action," Quarterly Journal of Speech, 70 (1984).

51. <http://www.uchronia.net/sidewise/complete.html > accessed may 30, 2011.

52. Baxter, Voyage; Gary Blackwood, The Year of the Hangman (New York: Dutton Books, 2002); Suzanne Alles Blom, Inca: The Scarlet Fringe (New York: Tor/Forge, 2000); Michael Chabon, The Yiddish Policemen's Union: A Novel (New York: Harper, 2007); Conroy, 1862: A Novel; Conroy, 1945: A Novel (New York: Ballantine 2006); Murray Davies, Collaborator (London: Macmillan UK, 2003); Peter Delacorte, Time on My Hands: A Novel with Pictures (New York: Scribner, 1997); Richard Dreyfuss and Harry Turtledove, The Two Georges (New York: Tor/Forge, 1995); Brendan Du Bois, Resurrection Day (New York: Jove Books, 2000); Mitchell Freedman, Disturbance of Fate (Santa Ana: Seven Locks Press, 2003); Stephen Fry, Making History (London: Hutchinson, 1996); Mary Gentle: Ash: A Secret History (New York: Eos, 1999); Gentle, Ilario: The Lion's Eye (London: Gollancz, 2006); Martin J. Gidron, The Severed Wing (Livingston: Livingston Press, 2002); Harry Harrison and John Holm, The Hammer and the Cross Trilogy, also treated as one novel, The Hammer and the Cross (London: Legend Press, 1993); One King's Way (London: Legend Press, 1995); King and Emperor (London: Legend Press, 1995); J. Gregory Keyes, The Age of Unreason (a tetralogy that the Sidewise panel treats as one novel); Newton's Cannon (New York: Del Rey, 1999), A Calculus of Angels (New York: Del Rey, 2000), The Empire of Unreason (New York: Del Rey, 2001), and The Shadows of God (New York: Del Rey, 2002); Ian MacLeod, The Summer Isles (Charleston: Aio, 2005); Sophia McDougall, Romanitas (London: Orion UK, 2005); McDougall, Rome Burning (London, Orion UK, 2006); Paul J. McAuley, Pasquale's Angel (London: Gollancz, 1994); Philip Roth, The Plot Against America (Boston: Houghton Mifflin, 2004); J.N. Stroyar, The Children's War (New York: Simon and Schuster, 2001); Turtledove, How Few Remain; Harry Turtledove, Ruled Britania (New York: NAL/Roc, 2002); Harry Turtledove, The Disunited States of America (New York: Tor/Forge, 2006); Jo Walton, Farthing (New York: Tor, 2006); Walton, Ha'penny (New York: Tor, 2007).

53. Baxter, Blackwood, Blom, Chabon, Conroy, Davies, Delacort, Dreyfuss and Turtledove, DuBois, Freedman, Gentle, Gidron, MacLeod, McDougall, Roth, Stroyar, Turtledove, and Walton.

54. Quoted in M.K. Goldberg, J.J. Brattin and M. Engel. On Heroes, Hero Worship and the Heroic in History (Berkeley: University of California Press, 1993), 52.

55. See, for example, General George Custer's resolute attempt to hang Abraham Lincoln in How Few Remain.

56. Gidron, 97.

57. To choose one minor example, the absence of the dichotomy between civilization and primitivism leads to some unusual political events, such as the new world political alliance between Cotton Mather, Blackbeard (formerly a pirate, now the governor of a small colony), and a Native American shaman (A Calculus of Angels, New York: Del Rey Books, 2000).

58. Sinclair Lewis' satirical 1935 novel It Can't Happen Here (New York: Signet Classics, 1993), which predicts (or forewarns of) the rise of totalitarianism in the United States was influential for many allohistorical authors but is not generally considered an alternate history. Although it appears to portray a deviation from the past, the novel is set in 1936, which at the time of its publication was the future.

59. While Roth has claimed that he was unaware of the genre before writing his novel, it is, apart from its critical attention, an exemplar of the alternate history.

60. Chabon, The Yiddish Policeman's Union, 375.

61. Chabon, The Yiddish Policeman's Union and Roth, The Plot Against America, for example.

62. Turtledove's How Few Remain, for example.

63. DuBois, Resurrection Day, for example.

64. See, for example, Thomas M. Disch, The Dreams Our Stuff is Made Of: How Science Fiction Conquered the World (New York: Free Press, 2000); Thomas Moylan, Scraps of the Untainted Sky: Science Fiction, Utopia, Dystopia (Boulder: Westview Press, 2000).

65. DuBois, Resurrection Day, 25.

66. Ibid., 249. Emphasis added.

67. Ibid., 308.

68. Among the excellent histories of the conservative movement over the last four decades, one could point to Lisa McGirr's Suburban Warriors: The Origins of the New American Right (Princeton: Princeton University Press, 2001); Kevin Kruse, White Flight: Atlanta and the Making 
of Modern Conservatism (Princeton: Princeton University Press, 2005); Joseph Crespino, In Search of Another Country: Mississippi and the Conservative Counterrevolution (Princeton: Princeton University Press, 2007); and Catherine Rymph, Republican Women: Feminism and Conservatism from Suffrage through the Rise of the New Right (Chapel Hill: University of North Carolina Press, 2006).

69. McGirr, Suburban Warriors, 149. The analysis of the growth of conservatism in the 1960s and 1970s presented here draws largely on McGirr's study, which focuses on grassroots conservatism in Orange County, California.

70. Gerald F. Seib, "Less is More: Libertarian Impulses Show Growing Appeal Among the Disaffected," Wall Street Journal, January 20, 1995.

71. President Bill Clinton, State of the Union address, January 27, 1996.

72. Deirdre R. Schwiesow, "The GenX Philosophy," USA Today, July 26, 1995. Quoted in Brian Doherty's Radicals for Capitalism (New York: Public Affairs, 2007), 532.

73. Doherty, Radicals for Capitalism, 532-536.

74. Andrew J. Bacevich, The New American Militarism: How Americans Are Seduced By War (London: Oxford University Press, 2005). My analysis here draws heavily on The New American Militarism, but also owes a debt to George Packer's Assassin's Gate: America in Iraq (New York: Farrar, Strous and Giroux, 2005) and Melani McAlister's Epic Encounters: Culture, Media \& U.S. Interests in the Middle East Since 1945 (Berkeley: University of California Press, 2001).

75. Bacevich, The New American Militarism, 108.

76. According to The Harris Poll, the military ranked first in polls of public confidence in institutions such as major education institutions, the U.S. Supreme Court, public schools, and the press from 2001-2007. The Harris Poll, March 1, 2007, <http://www.harrisinteractive.com/harris poll/ index.asp?PID=735>.

77. Bacevich, The New American Militarism, 23.

78. Many of Turtledove's novels would be high on this list.

79. Eric P. Seelau, Sheila M. Seelau, Gary L. Wells and Paul D. Windschitl, "Counterfactual Constraints," What Might Have Been: The Social Psychology of Counterfactual Thinking, eds. Neal J. Roese and James M. Olson (Mahwah: Lawrence Erlbaum Associates, 1995), 61.

80. In Disturbance of Fate, Bobby Kennedy survives his 1968 assassination to win the presidency and is re-election in 1972. In Voyage, John F. Kennedy's survival leads to a manned mission to Mars in 1969. Both novels are more even-handed than sanguine.

81. <http://www.uchronia.net/sidewise/complete.html> accessed May 30, 2011.

82. Steven Barnes, Lion's Blood: A Novel of Slavery and Freedom in an Alternate America (Tokyo: Aspect, 2002); Zulu Heart: A Novel of Slavery and Freedom in an Alternate America (Tokyo: Aspect, 2003).

83. See, for example, Barnes' interview on National Public Radio's "News \& Notes" on the topic of "Black Science Fiction and Fantasy," August 13, 2007.

84. Edward Schiappa, Beyond Representational Correctness: Rethinking Criticism of Popular Media (Albany: State University of New York Press, 2008), 61. 
